Mazurenko, B., Honchar, L., Garbar, L. (2021): Effect of nanoparticle metal solutions on chufa (Cyperus esculentus L.) root and seedling growth. Agriculture and Forestry, 67 (4): 131-140. doi:10.17707/AgricultForest.67.4.11

DOI: 10.17707/AgricultForest.67.4.11

\author{
Bohdan MAZURENKO, \\ Liubov HONCHAR, Lesya GARBAR ${ }^{1}$,
}

\title{
EFFECT OF NANOPARTICLE METAL SOLUTIONS ON CHUFA (CYPERUS ESCULENTUS L.) ROOT AND SEEDLING GROWTH
}

\section{SUMMARY}

Nanoparticles of trace elements are easily included in the metabolic cycles of plants. Zinc and molybdenum are important components of enzymes, but even at low concentrations can have phytotoxic effects. Treatment of chufa tubers with microelements increases the viability of tubers, but at certain concentrations of nanoparticles can negatively affect the growth processes at the germination and early vegetative stages. Effect of treatment of tubers with nanoparticle solution of molybdenum, zinc oxide and zinc citrate at a concentration of 20,40 and $60 \mathrm{ppm}$ on the growth of roots and seedlings was established on $3^{\text {rd }}$ and $10^{\text {th }}$ days after emergence. The positive effect of all treatments at a concentration of $20 \mathrm{ppm}$ was found, but higher concentrations caused different effects on root growth. Zinc citrate and molybdenum nanoparticle solution at a concentration of $60 \mathrm{ppm}$ adversely affect the weight of the root, leaves and root length. Pre-sowing treatment with zinc citrate is indirectly more effective than zinc oxide nanoparticles against root growth at concentrations of 20 and $40 \mathrm{ppm}$ but inhibits it at $60 \mathrm{ppm}$. Treatments with zinc oxide nanoparticles are more stable regardless of concentration. Short-term effects on root growth processes indicate the prospects of increasing drought resistance and other mechanisms of physiological adaptation.

Keywords: molybdenum, zinc, raw weight, root length, pre-seed treatment

\section{INTRODUCTION}

Chufa (Cyperus esculentus L.) is a drought-resistant crop with a high oil content in the tubers (Mokady and Dolev, 1970). High oil content in the reproductive organs can adversely affect the viability of the tubers (Pascual $e t$ al., 2000; Makareviciene et al., 2013). Micronutrients in a colloidal and nanoparticle form increase the sowing suitability of seeds and vegetative organs, but their

\footnotetext{
${ }^{1}$ Bohdan Mazurenko, (corresponding author: mazurenko.bohdan@nubip.edu.ua), Liubov Honchar, Lesya Garbar, Department of Plant Science, National University of Life and Environmental Sciences of Ukraine, UA03041 Kyiv, UKRAINE

Notes: The author declares that he has no conflicts of interest. Authorship Form signed online. 
effect has been little studied in non-traditional crops (Farooq et al., 2012). Nanoparticles are characterized by high absorption capacity and can be included in physiological cycles in a short time. NPs have a strong influence on the formation of elements of productivity in crops under foliar application (Tului et al., 2021), but their effect in the pre-seeds is manifested much earlier. Seed treatment by solutions of NPs can increase plant resistance to fungi and viral diseases, stimulate the growth of roots and stems (Bohdan et al., 2021).

The most important micronutrients are also heavy metals, and their excess can cause phytotoxicity (Taran et al., 2016). Treatment with different nanoparticle metal solution have a long-term effect of gradual growth of the chlorophyll index, dry matter accumulation and other important parameters of productivity (Son'ko et al., 2013; Islas- Valdez et al., 2020). New materials require the establishment of optimal parameters for their use, as the phytotoxicity of different compounds varies and depends on the species of plants (Singh et al., 2013). Pre-sowing treatment of tubers with nanoparticle solution is poorly understood because each plant species has its own ways of including micronutrients in metabolic cycles.

Purpose of this study is to establish the optimal rates of highly active nanoparticle solutions of $\mathrm{ZnO}$, zinc citrate and Mo NPs. Chufa has a relatively low threshold of phytotoxicity to nanometals, in particular various forms of zinc, because the concentration of $60 \mathrm{ppm}$ already has a negative effect on growth processes compared to control without treatment (Honchar et al., 2021). Molybdenum is an important element for plant growth because it is part of many enzyme systems, including those that counteract oxidative stress (Barker and Pilbeam, 2015). Molybdenum is low-toxic to plants (Marschner, 2012), but according to recent studies, even a concentration of $100 \mathrm{ppm}$ inhibits growth processes in Oryza sativa (Sharma et al., 2020) and $250 \mathrm{ppm}$ in Solanum tuberosum (Mushinskiy and Aminova, 2019). Morphologically and physiologically, chufa (family Cyperaceae) differs from cereals and dicotyledonous plants, so studies of the effect of nanometals on growth processes as a component of productivity are important.

\section{Experimental conditions}

\section{MATERIAL AND METHODS}

Laboratory tests were performed on tubers of chufa variety Pharaoh. Weight of 1 tuber was $1.14 \pm 0.02 \mathrm{~g}$. Tubers of chufa had planted in perlite. Air temperature during germination was $+22^{\circ} \mathrm{C}$. Chufa plants cultivated on a 12-hour light/12-hour dark cycle in controlled conditions in January of 2021. Preparation of nanoparticle solutions and laboratory research were performed in the laboratory of plant material quality in National University of Life and Environmental Sciences of Ukraine (Kyiv, Ukraine).

Tubers were treated with solutions of nanoparticles (zinc oxide nanoparticles - ZnO NPs; zinc citrate; molybdenum nanoparticles - Mo NPs) with a concentration of 20,40 and $60 \mathrm{ppm}$ on the day of planting. Variant without 
nanoparticle treatment (only water) was a control. Rate of consumption of the stock solution (500 $\mathrm{mg}$ of nanoparticle per litre) to pre-sowing treatment was 0.4 $(20 \mathrm{ppm}), 0.8(40 \mathrm{ppm})$ and $1.2(60 \mathrm{ppm})$ litre per tonne of tuber. Working solution to pre-sowing treatment was 10 litre per tonne of tubers.

\section{Sampling}

Mass of roots and leaves was determined on the $3^{\text {rd }}$ and $10^{\text {th }}$ day after seedling emergence. Ten plants $(n=10)$ from each variant were selected. Root system and leaf surface were weighed separately, the weight of the tuber was not taken into account. Root length was established as maximum length.

\section{Statistical analysis}

Suitability of the sample for statistical analysis was evaluated according to the Shapiro-Wilk test. Effect power on 3rd day and $10^{\text {th }}$ day was assessed by twoway ANOVA. Difference between the variants was assessed by Fisher`s LSD post-hoc test at $5 \%$ probability.

\section{RESULTS AND DISCUSSION}

\section{Root and leaf weight at $3^{\text {rd }}$ day after emergence}

Seed treatment with a solution of nanoparticles has a positive effect on the growth of the root system at a concentration of $20 \mathrm{ppm}$, but pre-sowing treatment with zinc citrate was more effective at $3^{\text {rd }}$ day after emergence (Fig. 1). Root weight in the treatment with zinc citrate in concentration 20 and $40 \mathrm{ppm}$ does not differ significantly from each other, but at $60 \mathrm{ppm}$ there is a significant inhibition of root growth (root weight is significantly lower than the control variant without treatments).

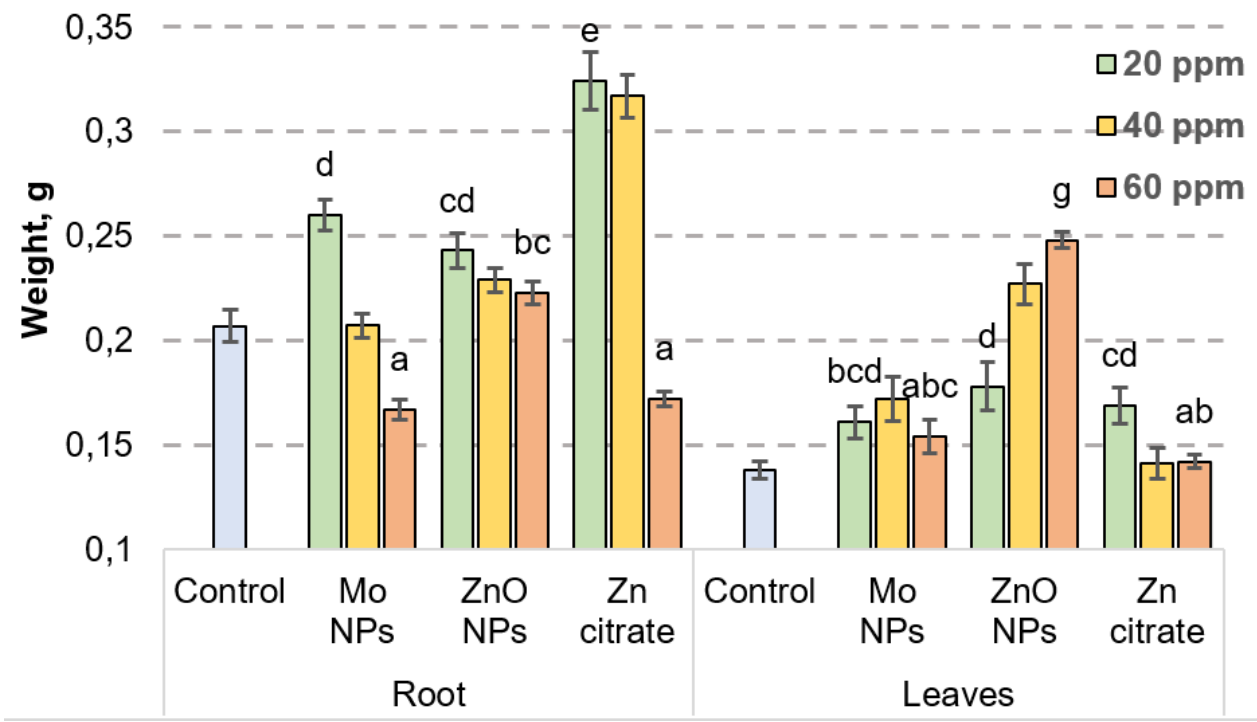

Figure 1. Root and leaf weight (g) depend on concentration of nanoparticle solutions in pre-seed treatment, 3rd day after emergence (Means followed by the same letter do not differ by the Fisher`s LSD test at 5\% probability) 
Treatment with $\mathrm{ZnO}$ NPs gives a smaller increase in percentage, but phytotoxicity is not manifested even at concentrations of $60 \mathrm{ppm}$, however, a significant increase is only at concentrations of 20 and $40 \mathrm{ppm}$. Mo NPs treatment has a higher contrast, because root weight increases at $20 \mathrm{ppm}$, but it significantly decreases at $40 \mathrm{ppm}$ and an even smaller root mass is formed by treatment at $60 \mathrm{ppm}$.

Formation of leaf mass compared with roots had a different response to pre-sowing treatment with nanoparticle solutions on $3^{\text {rd }}$ day after emergence. Leaf weight in treated variants with Mo NPs increased by 11.6-24.6 percent compared with the control one without a significant difference between the different concentrations. Pre-sowing treatment with $\mathrm{ZnO}$ NPs significantly increases the leaf weight and with increasing concentration the positive effect increases too. Zinc citrate has a much smaller effect on leaf mass. Significant increase in this indicator was at a concentration of $20 \mathrm{ppm}$ and there was no significant difference compared with control variant at an increase to 40 and $60 \mathrm{ppm}$ at $3^{\text {rd }}$ day after emergence.

Treatment with $\mathrm{ZnO}$ NPs has a positive effect at concentrations up to $9 \mu \mathrm{M}$ (equivalent $0.7 \mathrm{ppm}$ ), while simple zinc oxide is toxic to dicotyledonous plants in same concentration (Singh et al., 2013). Vigor and germination stay high even at a concentration of $80 \mathrm{ppm} \mathrm{ZnO} \mathrm{NPs} \mathrm{in} \mathrm{monocotyledons} \mathrm{(Esper} \mathrm{Neto} \mathrm{et} \mathrm{al.,} \mathrm{2020).}$ Phytotoxicity of zinc oxide nanoparticles in chufa may be at a much higher concentration than the studied ones.

\section{Root and leaf weight at $10^{\text {th }}$ day after germination}

Root weight has a more stable response to the concentration of the nanoparticle solutions at the $10^{\text {th }}$ day after emergence (fig. 2).

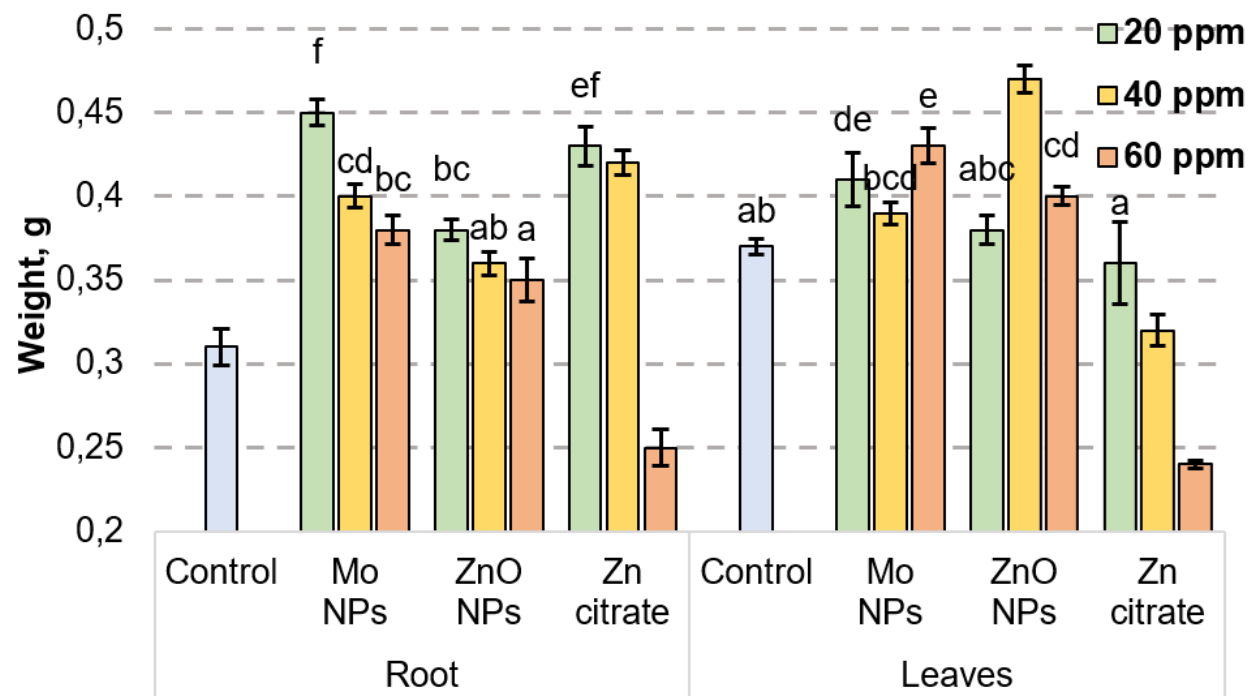

Figure 2. Root and leaf weight (g) depend on concentration of nanoparticles solution in pre-seed treatment, $10^{\text {th }}$ day after germination (Means followed by the same letter do not differ by the Fisher`s LSD test at 5\% probability) 
The most effective treatment is Mo NPs solution at a concentration of 20 $\mathrm{ppm}$. Root weight is $0.45 \mathrm{~g}$ in this variant, while it is $0.31 \mathrm{~g}$ in control variant. Root weight was $0.40 \mathrm{~g}$ at a concentration of $40 \mathrm{ppm}$, and it decreased insignificantly with increasing concentration to $60 \mathrm{ppm}$. Long-term effect of treatment with $\mathrm{ZnO}$ nanoparticles can be positive, but has species and varietal specificity (Batsmanova et al., 2020). Root mass significantly exceeded the control variant under treatment with $\mathrm{ZnO}$ NPs. It increases in concentration from 20 to $40 \mathrm{ppm}$ and root mass was significantly reduced at $60 \mathrm{ppm}$. Phytotoxicity of zinc citrate on the growth of the root system remains for a long period of time. Reason for the phytotoxicity of zinc citrate may be its greater digestibility (Montanha et al., 2020).

Leaf growth after germination is significantly slowed down, the manifestation of phytotoxicity is more stable. Leaf weight in treated variants with Mo NPs and ZnO NPs does not fluctuate significantly in percentage, then a significant inhibition of leaf growth occurs in treated variants with zinc citrate with increasing concentrations to 40 and $60 \mathrm{ppm}$.

\section{Plant weight}

Plant weight on the 3rd day after emergence is a marker of efficiency the utilization of tuber spare substances (fig. 3). Treatment of tubers with ZnO NPs significantly increases the plant weight with increasing concentration from 20 to $40 \mathrm{ppm}$, but the difference between 20 and $60 \mathrm{ppm}$ is insignificant. At the same time, pre-sowing treatment with zinc citrate with increasing concentration forms less plant weight and significant inhibit the growth processes at $60 \mathrm{ppm}$. Decrease in plant weight is gradual with increasing concentration of Mo NPs and growth processes are inhibited more at $60 \mathrm{ppm}$ (same to zinc citrate, $60 \mathrm{ppm}$ ).

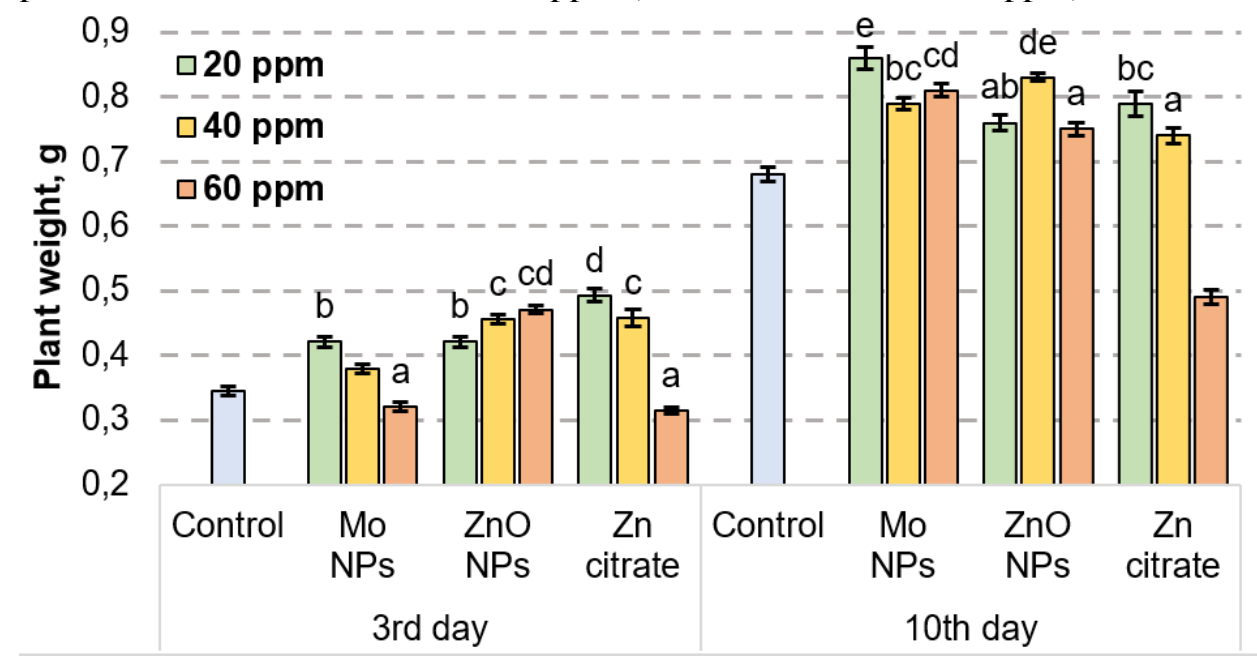

Figure 3. Plant weight (g) depends on concentration of nanoparticles solution in pre-seed treatment, $3^{\text {rd }}$ and $10^{\text {th }}$ day after germination (Means followed by the same letter do not differ by the Fisher`s LSD test at $5 \%$ probability) 
Plant weight in almost all nanoparticle solutions and their concentration effectively affect the plant weight, compared with the variant without treatment at $10^{\text {th }}$ day after emergence. Only the variant of zinc citrate at a concentration of 60 ppm had a negative effect on plant weight at this period. Elevated concentrations of zinc citrate in the plant can provoke long-term phytotoxicity (Flis et al., 2016).

\section{Root length}

Root length depended on the type of solution and its concentration (table 1). There was no significant difference in molybdenum NPs treatments between concentrations of 20 and $40 \mathrm{ppm}$ on $3^{\text {rd }}$ and $10^{\text {th }}$ day after emergence, but there was growth inhibition at a concentration of $60 \mathrm{ppm}$ (root length did not differ from the control variant). Pre-sowing treatment with Mo NPs can increase the length of roots in many plants, but certain species are more sensitive (Chhipa, 2017).

Treatment with $\mathrm{ZnO}$ NPs significantly increased root length, and there was no significant difference in different concentrations at $3^{\text {rd }}$ day after emergence. Root growth slowed and variant with treatment at concentration of $60 \mathrm{ppm}$ had shorter roots than 20 and 40 ppm ones at $10^{\text {th }}$ day after emergence.

Treatment of chufa tuber with zinc citrate at a concentration of $60 \mathrm{ppm}$ significantly inhibited root growth, which was manifested in a shorter root length $(10.7 \mathrm{~cm})$ than without treatments at $3^{\text {rd }}$ day after emergence. Root length was less at a higher concentration, but at the maximum concentration still exceeded the control variant at $10^{\text {th }}$ day after emergence. This indicates that phytotoxicity has begun to decrease.

Table 1. Root length depends on concentration of nanoparticle solutions in preseed treatment.

\begin{tabular}{lccc}
\hline Solution & $\begin{array}{c}\text { Concentration, } \\
\text { ppm }\end{array}$ & $3^{\text {rd }}$ day & $10^{\text {th }}$ day \\
\hline Control (water) & - & $13.3^{\text {ab }}$ & $13.6^{\mathrm{a}}$ \\
\hline \multirow{3}{*}{ Mo NPs } & 20 & $15.0^{\text {cd }}$ & $18.6^{\text {cd }}$ \\
& 40 & $14.5^{\text {bc }}$ & $19.3^{\text {d }}$ \\
\hline \multirow{2}{*}{ ZnO NPs } & 60 & $12.2^{\mathrm{a}}$ & $13.8^{\text {ab }}$ \\
& 20 & $16.0^{\text {cde }}$ & $20.1^{\text {de }}$ \\
& 40 & $16.1^{\text {de }}$ & $19.6^{\mathrm{d}}$ \\
Zn citrate & 60 & $15.5^{\text {cd }}$ & $17.2^{\mathrm{c}}$ \\
& 20 & $17.3^{\mathrm{e}}$ & $21.6^{\mathrm{e}}$ \\
& 40 & $16.3^{\mathrm{de}}$ & $18.6^{\mathrm{cd}}$ \\
\hline
\end{tabular}

Means in column followed by the same letter do not differ by the Fisher`s LSD test at $5 \%$ probability.

Root length in treated variants with $\mathrm{ZnO}$ NPs in chufa began to decrease at a concentration of $60 \mathrm{ppm}$, while the concentration of $80 \mathrm{ppm}$ had a positive effect in corn (Esper Neto et al., 2020). 


\section{Correlation between root length root, leaf and plant weight}

Concentration of the studied solution had a negative correlation with root weight on the $3^{\text {rd }}$ and $10^{\text {th }}$ day after emergence $(p<0.01)$, but this effect was much weaker and significant only at the level of $\mathrm{p}<0.05$ in treated variants with $\mathrm{ZnO}$ NPs (table 2).

Table 2. Linear correlation coefficients

\begin{tabular}{lcccc}
\hline Solution & Root weight & Leaf weight & Plant weight & Root length \\
\hline \multicolumn{5}{c}{$3^{\text {rd }}$ day after emergence } \\
\hline Mo colloidal & $-0.89^{* *}$ & $-0.10^{\text {ns }}$ & $-0.87^{* *}$ & $-0.65^{* *}$ \\
Zn colloidal & $-0.38^{*}$ & $0.72^{* *}$ & $0.67^{* *}$ & $-0.14^{\text {ns }}$ \\
Zn citrate & $-0.81^{* *}$ & $-0.45^{*}$ & $-0.88^{* *}$ & $-0.78^{* *}$ \\
\hline \multicolumn{5}{c}{$10^{\text {th }}$ day after emergence } \\
\hline Mo colloidal & $-0.76^{* *}$ & $0.21^{\mathrm{ns}}$ & $-0.42^{*}$ & $-0.67^{* *}$ \\
Zn colloidal & $-0.41^{*}$ & $0.18^{\mathrm{ns}}$ & $-0.09^{\text {ns }}$ & $-0.53^{* *}$ \\
Zn citrate & $-0.83^{* *}$ & $-0.72^{* *}$ & $-0.89^{* *}$ & $-0.78^{* *}$ \\
\hline$* \mathrm{p}<0.05 ; * * \mathrm{p}<0.01 ;^{\mathrm{ns}}-$ no significant.
\end{tabular}

Relationship between concentration of nanoparticle and leaf weight varied depend on type of solution and observation time. The increase in concentration had a positive correlation with leaf weight on $3^{\text {rd }}$ day, but there was no such effect on $10^{\text {th }}$ day. This indicates that zinc from ZnO NPs is involved in improving the reutilization of tuber spare substances for leaf formation during germination. The concentration of molybdenum nanoparticles was not significantly related to leaf weight at $3^{\text {rd }}$ and $10^{\text {th }}$ day after emergency, because Mo do not take part in leaf formation processes in early stages, but important during active dry mass assimilation (Rana et al., 2020). Negative correlation between zinc citrate concentration and leaf mass may be occurred by toxicity caused by increased "non-profit" zinc, which is not included in biological cycles (Ullah et al., 2019).

Plant weight had a negative correlation with increasing concentration of zinc citrate and Mo NPs on $3^{\text {rd }}$ and $10^{\text {th }}$ day after emergence. Plant weight increased at a higher concentration in treated variants with $\mathrm{ZnO}$ NPs with on $3^{\text {rd }}$ day, but the effect of concentration had no statistically significant effect on $10^{\text {th }}$ day. Short-term positive reactions to $\mathrm{ZnO}$ nanoparticle treatment are typical of a wide range of organism (Rajput et al., 2018).

Effect of concentration on the maximum root length was negative in most treatment variants on $3^{\text {rd }}$ and $10^{\text {th }}$ day, exclude $\mathrm{ZnO}$ NPs at $3^{\text {rd }}$ day, when this correlation was insignificant.

The positive effect on biometric parameters at different concentrations was caused the ability of zinc nanoparticles to reduce overall phytotoxicity, inducing over expression of antioxidant defense enzymes (Venkatachalam et al., 2017). However, the negative effect of increasing the concentration of zinc may be manifested at lower rates than in other plants (Liu et al., 2016). 
Nanoparticle treatment of tubers can affect the architecture of the root system, changing the ratio of roots of different lengths and inducing the growth of many short hairs. Root weight was increased with increasing concentration of $\mathrm{ZnO}$ NPs, but its length decreased, which is a consequence of these processes. The obtained results are consistent for other crops with a fibrous root system, as nanoparticles also have a positive effect on the growth of secondary roots (Estrada-Urbina et al., 2018).

\section{CONCLUSIONS}

Pre-sowing treatment of tubers with metal nanoparticle solutions has different effects on the growth of roots and seedlings. Molybdenum nanoparticle solution is characterized by negative effects on root and seedling growth at a concentration of $40 \mathrm{ppm}$ on the 3rd day after emergence, but short-term phytotoxicity can be overcome, and the treatment efficiency is better than in the control variant on the $10^{\text {th }}$ day after emergence. Negative effect of Mo NPs at concentration of $60 \mathrm{ppm}$ on the growth of the root system requires further study. $\mathrm{ZnO}$ NPs in a concentration from 20 to $60 \mathrm{ppm}$ has a positive effect on the weight of the plant, root and stem, root length, but the most effective for a combination of different indicators is the treatment at a concentration of $40 \mathrm{ppm}$. Pre-sowing treatment with zinc citrate has more phytotoxic effect on leaf growth than other NPs solutions. Negative effect is observed at a concentration of $60 \mathrm{ppm}$ on the $3^{\text {rd }}$ day after emergence, and slightly weakens on the $10^{\text {th }}$ day under zinc citrate treatment. Pre-sowing treatment with $\mathrm{ZnO}$ NPs is highly effective at a concentration of $20-60 \mathrm{ppm}$, while zinc citrate has a stable effect only at 20 and $40 \mathrm{ppm}$.

\section{REFERENCES}

Barker, A. V., \& Pilbeam, D. J. (Eds.). (2015): Handbook of plant nutrition. CRC press.

Batsmanova, L., Taran, N., Konotop, Y., Kalenska, S., \& Novytska, N. (2020): Use of a colloidal solution of metal and metal oxide-containing nanoparticles as fertilizer for increasing soybean productivity. Journal of Central European Agriculture, 21(2): 311-319.

Bohdan, M., Huliaieva, H., Patyka, M., Kalinichenko, A., Patyka, V., Maksin, V. (2021): Enhancement of wheat virus-resistance at application of the se nanoparticles citrates and consortium of soil microorganisms. Agriculture and Forestry, 67 (1): 63-72.

Chhipa, H. (2017): Nanofertilizers and nanopesticides for agriculture. Environmental Chemistry Letters, 15(1): 15-22.

Esper Neto, M., Britt, D. W., Lara, L. M., Cartwright, A., dos Santos, R. F., Inoue, T. T., \& Batista, M. A. (2020): Initial development of corn seedlings after seed priming with nanoscale synthetic zinc oxide. Agronomy, 10(2): 307.

Estrada-Urbina, J.; Cruz-Alonso, A.; Santander-Gonzalez, M.; Mendez-Albores, A.; Vazquez-Duran, A. (2018): Nanoscale zinc oxide particles for improving the physiological and sanitary quality of a mexican landrace of red maize. Nanomaterials, 8: 1-12. 
Farooq, M., Wahid, A., \& Siddique, K. H. (2012): Micronutrient application through seed treatments: a review. Journal of Soil Science and Plant Nutrition, 12(1): 125-142.

Flis, P., Ouerdane, L., Grillet, L., Curie, C., Mari, S., \& Lobinski, R. (2016): Inventory of metal complexes circulating in plant fluids: a reliable method based on HPLC coupled with dual elemental and high- resolution molecular mass spectrometric detection. New Phytologist, 211(3): 1129-1141.

Honchar, L., Mazurenko, B., Shutyi, O., Pylypenko, V., \& Rakhmetov, D. (2021): Effect of pre-seed and foliar treatment with nano-particle solutions on seedling development of tiger nut (Cyperus Esculentus L.) plants. Agronomy research, 19 (S1): 767-776.

Islas-Valdez, S., López-Rayo, S., Arcos, J., Menéndez, N., \& Lucena, J. J. (2020): Effect of Fe: ligand ratios on hydroponic conditions and calcareous soil in Solanum lycopersicum L. and Glycine max L. fertilized with heptagluconate and gluconate. Journal of the Science of Food and Agriculture, 100(3): 1106-1117.

Liu, R., Zhang, H., \& Lal, R. (2016): Effects of Stabilized Nanoparticles of Copper, Zinc, Manganese, and Iron Oxides in Low Concentrations on Lettuce (Lactuca sativa) Seed Germination: Nanotoxicants or Nanonutrients? Water, Air, \& Soil Pollution, 227(1).

Makareviciene, V., Gumbyte, M., Yunik, A., Kalenska, S., Kalenskii, V., Rachmetov, D., \& Sendzikiene, E. (2013): Opportunities for the use of chufa sedge in biodiesel production. Industrial Crops and Products, 50: 633-637.

Marschner, P. (2012): Marschner's mineral nutrition of higher plants 3rd edition. Academic Press, London. 672.

Mokady, S. H., \& Dolev, A. (1970): Nutritional evaluation of tubers of Cyperus esculentus L. Journal of the Science of Food and Agriculture, 21(4): 211-214.

Montanha, G. S., Rodrigues, E. S., Romeu, S. L., de Almeida, E., Reis, A. R., Lavres Jr, J., \& de Carvalho, H. W. P. (2020): Zinc uptake from $\mathrm{ZnSo}_{4}$ (aq) and $\mathrm{Zn-EDTA}$ (aq) and its root-to-shoot transport in soybean plants (Glycine max) probed by time-resolved in vivo X-ray spectroscopy. Plant Science, 292, 110370.

Mushinskiy, A. A., \& Aminova, E. V. (2019, October): The effect of nanoparticles of iron, copper and molybdenum on the morphometric parameters of plants Solanum tuberosum L. In IOP Conference Series: Earth and Environmental Science (Vol. 341, No. 1, p. 012181). IOP Publishing.

Pascual-Seva, N., Pascual, B., San Bautista, A., López-Galarza, S., \& Maroto, J. V. (2009): Growth and nutrient absorption in chufa (Cyperus esculentus L. var. sativus Boeck.) in soilless culture. The Journal of Horticultural Science and Biotechnology, 84(4): 393-398.

Rajput, V. D., Minkina, T. M., Behal, A., Sushkova, S. N., Mandzhieva, S., Singh, R., Gorovtsov, A., Tsitsuashvili, V. S., Purvis. W. O., Ghazaryan K. A., \& Movsesyan, H. S. (2018): Effects of zinc-oxide nanoparticles on soil, plants, animals and soil organisms: a review. Environmental Nanotechnology, Monitoring \& Management, 9: 76-84.

Rana, M. S., Sun, X., Imran, M., Ali, S., Shaaban, M., Moussa, M. G., Khan, Z., Afzal, J., Binyamin, R., Bhantana, P., Alam, M., Din, I. U., Younas, M. \& Hu, C. (2020): Molybdenum-induced effects on leaf ultra-structure and rhizosphere phosphorus transformation in Triticum aestivum L. Plant Physiology and Biochemistry, 153: 20-29. 
Sharma, P. K., Raghubanshi, A. S., \& Shah, K. (2021): Examining the uptake and bioaccumulation of molybdenum nanoparticles and their effect on antioxidant activities in growing rice seedlings. Environmental Science and Pollution Research, 28(11): 13439-13453.

Singh, N. B., Amist, N., Yadav, K., Singh, D., Pandey, J. K., \& Singh, S. C. (2013): Zinc oxide nanoparticles as fertilizer for the germination, growth and metabolism of vegetable crops. Journal of Nanoengineering and Nanomanufacturing, 3(4): 353364.

Son'ko, R. V., Starodub, N. F., Trach, V. V., \& Lopat'ko, K. G. (2013): Effect of colloidal metals on the induced chlorophyll fluorescence at the different lupin state. In Biophotonics-Riga 2013. Vol. 9032: 90320Z.

Taran, N., Batsmanova, L., Kosyk, O., Smirnov, O., Kovalenko, M., Honchar, L., \& Okanenko, A. (2016): Colloidal nanomolybdenum influence upon the antioxidative reaction of chickpea plants (Cicer arietinum L.). Nanoscale research letters, 11(1): 1-5.

Tului, V., Janmohammadi, M., Abbasi, A., Vahdati-Khajeh, S., \& Nouraein, M. (2021): Influence of iron, zinc and bimetallic $\mathrm{Zn}-\mathrm{Fe}$ nanoparticles on growth and biochemical characteristics in chickpea (Cicer arietinum) cultivars. Agriculture and Forestry, 67(2): 179-193.

Ullah, A., Farooq, M., Hussain, M., Ahmad, R., \& Wakeel, A. (2019): Zinc seed coating improves emergence and seedling growth in desi and kabuli chickpea types but shows toxicity at higher concentration. International Journal of Agriculture and Biology, 21: 553-559.

Venkatachalam, P., Jayaraj, M., Manikandan, R., Geetha, N., Rene, E. R., Sharma, N. C., \& Sahi, S. V. (2017): Zinc oxide nanoparticles (ZnO NPs) alleviate heavy metalinduced toxicity in Leucaena leucocephala seedlings: A physiochemical analysis. Plant Physiology and Biochemistry, 110: 59-69. 